\title{
SENI PERTUNJUKAN RITUAL DALAM UPACARA LABUHAN DI PARANGKUSUMA
}

\author{
Y. Murdiyati ${ }^{1}$
}

\begin{abstract}
The study aims to understand, to analyses, and to descript the meaning of the Bedaya Sangga Buwana Dance in the ritual ceremony and to add or to increase the meaning of the dance in the ritual ceremony in Parangkusuma. The existence of ritual ceremony in Parangkusuma has aim role thank to the God, and ask the health. The conclution of the article is: (a) the ceremony and traditional ritual aim to continu and to increase the culture values, (b) the ceremony and the traditional ritual are hoped as the instrument of connection between the nations in the world, and (c) the Bedaya Sangga Buwana Dance is connected with the ritual ceremony.
\end{abstract}

Keywords: performance art, ceremony, and Parangkusuma.

Parangkusuma merupakan nama salah satu lokasi yang dipandang keramat di Kawasan Pantai Parangtritis. Dikatakan keramat antara lain karena lokasi itu sebagai petilasan atau pernah dipakai untuk pertemuan Sutawijaya (Panembahan Senapati) dengan Kanjeng Ratu Kidul, yang ditandai dengan dua "Batu Gilang." Dalam budaya Jawa, lokasi tersebut dianggap sebagai gerbang utama menuju Kraton Gaib Laut Selatan, tempat tokoh mitos Kanjeng Ratu Kidul memerintah, maka upacaraupacara labuhan oleh masyarakat, baik kraton maupun masyarakat umumnya, diselenggarakan di Pantai Parangkusuma (Tourism Map of Bantul Regency, t.t.: 07).

${ }^{1}$ Y. Murdiyati adalah Dosen Jurusan Tari Fakultas Seni Pertunjukan Institut Seni Indonesia Yogyakarta. 
Parangkusuma yang terletak 1.000 meter di sebelah barat Parangtritis menjadi objek wisata spiritual. Tempat ini sangat sakral dan mistis, karena memiliki sejarah yang berkaitan dengan berdirinya Kerajaan Mataram. Ketika Panembahan Senapati ingin melepaskan diri dari Kesultanan Demak, atas nasihat Ki Juru Martani pamannya, beliau harus bertapa dahulu di pantai selatan untuk mendapatkan kekuatan gaib dari Tuhan Yang Maha Esa berupa wahyu kraton. Pesannya bahwa untuk menuju pantai laut selatan dengan laku menghanyutkan diri mengikuti aliran Sungai Opak. Setibanya di muara sungai itu baru turun menyusuri pantai menuju selatan bukit Sentana. Dalam pengamatannya, Ki Juru Martani bertapa di Gunung Merapi, sehingga mereka terpisah, sedangkan Panembahan Senapati ke pantai laut selatan lewat Sungai Opak.

Setelah tiba di selatan Bukit Sentana, beliau lalu bersemadi atau bertapa di atas batu hitam yang disebut Sela Dhampar atau Batu Gilang untuk mendapatkan wahyu kraton Mataram. Ketika mengheningkan cipta, Panembahan Senapati dijumpai Kanjeng Ratu Kidul yang menyampaikan gambaran bahwa Panembahan Senapati sebagai calon raja di Mataram. Dengan perasaan lega beliau bersuka cita, bahkan berlanjut hingga kedua pihak saling mencintai (Suparno, 2004: 16-17). Menurut Damarjati Supadjar (wawancara pada 11-4-2008), Panembahan Senapati memperisteri Kanjeng Ratu Kidul itu sebuah peristiwa mistik luar biasa, tetapi bergeser menjadi mitos; orang Jawa itu suka menghormati orang lain, bahkan pusaka saja dihormati, dan ini sebagai orientasi budaya. Oleh sebab itu wajar bila Parangkusuma mendapat penghormatan sebagai tempat upacara ritual.

Dalam setiap masa krisis diperlukan hadirnya sesuatu yang transenden dan semua itu dilakukan melalui upacara. Upacara dengan sarana kesenian tetap bertolak dari makna upacara itu sendiri. Ketika terjadi krisis bersama, manusia menghadirkan kekuatan kosmos untuk mengatasi krisis itu (Sumardjo, 2000: 329), misalnya menyelenggarakan upacara labuhan, bersih desa dan sebagainya. Konsep kesatuan kosmos hanya dapat diperoleh melalui sistem kepercayaan, maka pengetahuan tentang kosmologi kepercayaan mereka menjadi sangat utama (Sumardjo, 2000: 323).

Berbicara tentang kepercayaan, masyarakat Jawa umumnya percaya terhadap mitologi Kanjeng Ratu Kidul. Mitologi bermaksud mengungkap kehadiran yang suci melalui simbol dan konsep (Twikromo, 
2006: 69). Manusia Jawa menghadirkan Yang Ilahi atau Yang Suci dalam kehidupan melalui praktik-praktik keagamaan atau mitologi. Kehadiran Yang Suci itu diharapkan untuk menjaga keseimbangan dunia dan agar tidak terjadi berbagai gangguan atau bencana alam menimpa kehidupan manusia. Pandangan-pandangan masyarakat Jawa terhadap dunianya ini benar-benar dihayati dan mitos digunakan sebagai pegangan dalam kehidupannya. Mitologi Kanjeng Ratu Kidul sangat berpengaruh terhadap kehidupan mereka, bahkan hampir seluruh orang Jawa mengenalnya selaku penguasa Laut Selatan. Hal ini sebagai bukti bahwa mitologi Kanjeng Ratu Kidul telah menjadi warisan budaya yang diwariskan secara turun-temurun.

Mitologi merupakan cerita suci yang diturunkan secara lisan kepada keturunannya, sehingga dalam perkembangan banyak mengalami pengurangan dan penambahan yang memunculkan bermacam-macam versi cerita. Namun demikian, maksud dan tujuan keberadaan mitologi itu tetap sama (Twikromo, 2006: 70).Dapat dikatakan bahwa mitos tersebut tidak hanya merupakan realitas kultural yang benar-benar terjadi, tetapi memang telah menjadi kepercayaan masyarakat pendukungnya, sehingga banyak anggota masyarakat yang melakukan wisata-ziarah di Parangkusuma. Mengingat kepercayaan itu ada dalam alam pikiran orang Jawa untuk mendapatkan keselamatan, ketenteraman, dan keseimbangan antara alam adikodrati dan alam kodrati agar tidak terjadi bencana alam, maka komunitas atau masyarakat menyelenggarakan upacara ritual dengan perlengkapan sesaji. Doa-doa yang diucapkan ketika upacara berlangsung menunjukkan bahwa upacara tersebut untuk memohon keselamatan, ketenteraman dan perlindungan agar tidak terjadi lagi bencana alam. Perlengkapan saji-sajian yang dipersembahkan antara lain berupa bunga (melati, mawar, kanthil, kenanga), buah-buahan, sayuran, padi, iwen, unggas, kain, semekan/kemben dan uang ala kadarnya.

Dalam aktivitas ini terjadi hubungan sakral antara Kanjeng Ratu Kidul dan komunitas atau masyarakat yang menyelenggarakan upacara melalui getaran jiwa, ekspresi perasaan atau emosi, dan suara batin. Peristiwa ini juga terjadi bagi para pelaku wisata-ziarah, karena ketika mereka berdoa, bersemadi, bermeditasi untuk memohon keselamatan, ketenteraman dan perlindungan juga terjadi upacara ritual dan hubungan sakral dengan Kanjeng Ratu Kidul melalui getaran jiwa, ekspresi perasaan atau emosi dan suara batin. Dengan demikian antara upacara 
ritual dan wisata-ziarah ada hubungan timbal balik, yakni dalam upacara ritual terjadi wisata-ziarah, sebaliknya dalam wisata-ziarah terjadi pula upacara ritual.

Dalam era modernisasi ini, kebudayaan Jawa yang berkaitan dengan Parangkusuma, upacara ritual labuhan dan kepercayaan mitos Kanjeng Ratu Kidul, yang sering dianggap tidak rasional, ternyata masih dilestarikan dan dikembangkan oleh masyarakat atau komunitas pemiliknya. Bahkan berpengaruh dalam kehidupan sehari-hari khususnya bagi masyarakat di sekitarnya. Dalam usaha untuk memohon keselamatan, ketenteraman lahir batin, terhindar dari bencana alam dan sebagainya, Parangkusuma dijadikan sasaran untuk berwisata-ziarah dengan cara mengadakan upacara ritual selamatan, labuhan, bersemadi, bermeditasi atau berdoa dan sebagainya yang menurut kepercayaan masyarakatnya merupakan persembahan kepada Kanjeng Ratu Kidul penguasa Laut Selatan, walaupun semuanya itu ditujukan kepada Allah.

Mengingat Parangkusuma merupakan tempat ziarah, keramat/ sakral/suci, wingit, juga petilasan pertemuan antara Sutawijaya (Panembahan Senapati) dan Kanjeng Ratu Kidul, maka diharapkan wisatawan yang berziarah di tempat itu bertindak sopan sesuai dengan makna-makna tersebut. Apalagi mengingat Kanjeng Ratu Kidul sebagai ratu makhluk halus yang memiliki kekuatan supranatural yang jarang dimiliki oleh orang biasa. Dalam pertemuan itu terjadi kisah perjanjian tentang hubungan antara Kerajaan Mataram dan Kraton Laut Selatan, yakni keturunan Panembahan Senapati yang menjadi raja Jawa bila menginginkan kerajaan dan seluruh rakyatnya tenteram, maka raja yang sedang berkuasa harus mengadakan hubungan dengan Kanjeng Ratu Kidul. Hubungan itu ditandai dengan persembahan atau upacara sesaji kepada Kanjeng Ratu Kidul, dan akan dibalas dengan memberikan bantuan keamanan serta keselamatan kepada raja dan seluruh rakyatnya (Twikromo, 2006: 101).

Upacara ritual di Parangkusuma yang menggunakan seni pertunjukan antara lain upacara labuhan oleh komunitas Sanggar Supranatural Sangga Buwana pimpinan Lia Hermin Putri yang sejak tanggal 7 September 2006 diselenggarakan dengan sarana Tari Bedaya Sangga Buwana ciptaan Jiyu Wijayanti. Upacara merupakan proses terwujudnya hubungan rohani antara manusia dan Tuhan Yang Maha Kuasa; dalam upacara itu manusia selalu berusaha mendekatkan diri kepada Tuhan melalui sistem komunikasi yang secara bersamaan 
didukung oleh masyarakat; wujud komunikasi itu bermacam-macam tetapi tujuannya satu yang pada garis besarnya sebagai syukuran atas karya manusia dan kerukunan yang telah diciptakan (Wibowo, 2005: 125). Menurut Hermien Kusmayati (2000: 12), upacara merupakan kehendak bersama suatu masyarakat yang ungkapannya diwujudkan melalui media gerak, suara dan rupa, yang sajiannya mengetengahkan aspek estetis koreografis.

Dengan demikian, proses terwujudnya komunikasi dalam upacara itu termasuk ritual. Pengertian ritual menurut Sumandiyo Hadi (1999/ 2000: 30) adalah suatu bentuk upacara atau perayaan yang berhubungan dengan beberapa kepercayaan atau agama, dengan ditandai oleh sifat khusus, yang menimbulkan rasa hormat yang luhur dalam arti merupakan pengalaman yang suci. Dengan demikian, yang disebut upacara ritual adalah ungkapan kehendak suatu masyarakat melalui gerak, suara dan rupa dengan aspek-aspek estetis koreografis, dan berkaitan dengan kepercayaan atau agama, menimbulkan rasa hormat serta merupakan pengalaman yang suci.

Alasan pemilihan upacara labuhan karena: (a) eksistensi upacara itu langka dan melibatkan seni pertunjukan ritual yakni Tari Bedaya Sangga Buwana; (b) kegiatan upacara diselenggarakan di Parangkusuma, bukan di tempat lain. Dari argumentasi ini, pasti ada sesuatu yang dalam dan penting yang melatarbelakangi kehadiran upacara labuhan dan tari Bedaya Sangga Buwana. Dapat dikatakan bahwa upacara labuhan di Parangkusuma berkaitan erat dengan konsep kepercayaan mitos Kanjeng Ratu Kidul.

Menurut Eliade (Susanto, 1987: 71-72), mitos merupakan dasar kehidupan sosial dan kebudayaan manusia, sebagai sejarah kudus tentang sesuatu yang terjadi, kenyataan kudus dan realitas sosial. Mitos adalah cerita yang memberikan pedoman dan arah tertentu kepada sekelompok orang, dapat dituturkan melalui tari-tarian dan inti ceritanya merupakan lambang-lambang yang mencetuskan pengalaman manusia: dosa-dosa dan penyucian, perkawinan, kesuburan dan sebagainya (Peursen, 1976: 37). Mitos merupakan cerita tentang peristiwa-peristiwa semihistoris yang menerangkan masalah-masalah akhir kehidupan manusia (Havilland, 1999: 229). Dengan demikian, mitos adalah cerita kenyataan atau peristiwa yang benar-benar terjadi, bermakna kudus, sehingga menjadi cerita tradisi yang esensinya bertuah dan berguna bagi kehidupan masyarakat pendukungnya. 
Dengan adanya mitos pertemuan Kanjeng Ratu Kidul dengan Sutawijaya, maka tiada mustahil bila atas dasar kepercayaan mitos, masyarakat di lingkungan kraton dan pedesaan khususnya di sekitar Parangkusuma selalu menyelenggarakan upacara ritual labuhan. Upacara labuhan adalah upacara membuang sesuatu yang bermakna ke dalam laut, dalam penelitian ini laut selatan, tempat Kanjeng Ratu Kidul berkuasa. Dengan kata lain, masyarakat tersebut dengan cara Ilahi mempersembahkan sesuatu kepada Kanjeng Ratu Kidul sebagai perantara ucapan syukur atas keberhasilan yang telah dicapai dan permohonan keselamatan, ketenteraman serta kesuksesan mereka kepada Allah. Salah satu upacara labuhan yang menggunakan seni pertunjukan tari adalah upacara labuhan yang diselenggarakan oleh komunitas Sanggar Supranatural Sangga Buwana pimpinan Lia Hermin Putri, yang berdiri pada tanggal 22 Juli 2003 di Parangtritis (wawancara dengan Putri, pada 24-7-2008). Mengingat keberadaan tari itu dilatarbelakangi oleh kebutuhan upacara ritual oleh Sanggar Supranatural Sangga Buwana, maka tari itu disebut "Bedaya Sangga Buwana" (wawancara dengan Wijayanti, pada 26-11-2007).

Dalam perumusan Tari Bedaya Sangga Buwana sebagai sarana upacara labuhan dipakai perspektif etnoart. Etnoart adalah bagian dari etnosains yang berkenaan dengan seni (Putra, 2005: 110). Dijelaskan lebih lanjut, mengingat dalam seni terdapat berbagai cabang, yakni seni tari, musik, lukis, patung dan sebagainya, maka etnoart atau etnoseni juga dapat dibedakan menjadi etnotari, etnomusik, etnolukis, etnopatung dan sebagainya. Etnoart pada dasarnya adalah kajian tentang seni dengan perspektif emic atau lokal, yakni deskripsi tentang seni dengan mengambil perspektif pendukung seni atau orang yang diteliti. Perspektif emic merupakan perspektif sukubangsa atau masyarakat yang diteliti atau perspektif etno. Dalam kajian seni pertunjukan, topik yang menarik antara lain tentang etnoestetika, karena peneliti mempertanyakan kembali keuniversalan kaidah-kaidah estetika. Selain itu, kajian etnoart juga dapat mengungkap elemen-elemen yang banyak digunakan untuk menciptakan karya seni dan tolok ukur keindahan terhadap seni oleh sukubangsa atau masyarakat yang memiliki seni tersebut. Manfaat kajian etnoart adalah: (a) akan mendorong peneliti berusaha mengungkapkan makna-makna berbagai kesenian yang dikenal, dihasilkan dan dipentaskan oleh suatu masyarakat; (b) akan menghasilkan deskripsi fenomena kesenian yang lebih menghargai pandangan-pandangan yang berasal dari masyarakat 
yang diteliti, dan ini memberikan dampak positif terhadap pandangan masyarakat tersebut tentang penelitian kesenian; dan (c) akan mendorong dihasilkannya sarana dan teknik pelukisan fenomenologi kesenian yang baru, yang selain bersifat universal juga masih memperhitungkan kekhasan serta dimensi pemaknaan yang diberikan oleh pelaku kesenian itu sendiri (Putra, 2005: 112-113).

Keterlibatan tari Bedaya Sangga Buwana dalam upacara labuhan oleh komunitas Sanggar Supranatural Sangga Buwana diharapkan memberikan makna yang dalam, karena penyelenggaraan upacara labuhan tersebut biasanya tidak menggunakan tari bedaya sebagai sarana upacara. Oleh sebab itu, penulisan ini bertolak dari masalah pemaknaan Tari Bedaya Sangga Buwana dalam Upacara Labuhan oleh Komunitas Sanggar Supranatural Sangga Buwana Tujuan penulisan ini antara lain untuk: (a) merumuskan pemaknaan Tari Bedaya Sangga Buwana dalam Upacara Labuhan oleh Komunitas Sanggar Supranatural Sangga Buwana; dan (b) memperkaya pemaknaan tari dalam upacara ritual di Parangkusuma.

\section{PERTUNJUKAN RITUAL DALAM UPACARA LABUHAN}

Arti Sangga Buwana dalam logo Sanggar Supranatural Sangga Buwana adalah sebagai berikut:

1). Kita sangga bumi ini dengan kedua tangan yang lemah dengan harapan kita mampu menjunjung tinggi Bumi Pertiwi yang kita cintai dengan harapan menunaikan amanat Tuhan untuk menjaga, merawat dan menyayangi Buni ini beserta isinya yang bermacammacam makna yang terkandung di dalam Bumi. Kita harus dapat menerima dengan kedua tangan kita yang lemah ini dengan beraneka ragam masalah, problema, perkara, cobaan, terpaan badai, fitnah, keangkaramurkaan, perselisihan dan lain-lain.

2). Dan kita sebagai Supranatural hanya mampu menengadahkan tangan memohon pada Tuhan untuk meminta Keridhoan-Nya agar tangan kami mampu membantu orang-orang untuk kesembuhan sakitnya. Karena hanya Tuhan yang memiliki Dzat segala Dzat penyembuh Penyakit apa saja. 
Sedangkan motto Sangga Buwana adalah Mamasuh Malaning Bumi, Mangasah Mingising Budi yang berarti: "Membasuh Lukanya Bumi, Mengasah Tajamnya Budi.” Tidak ada hal yang mustahil, apa pun dapat terjadi karena manusia memiliki kemampuan yang luar biasa, untuk menjelmakan suatu keinginan menjadi kenyataan (wawancara dengan Putri, pada 24-7-2008).

Lebih lanjut Putri mengatakan, karena pembenahan nurani merupakan kunci segala penyelesaian masalah bangsa bahkan dunia, maka banyak hal yang dapat dilakukan yang titik tumpu utamanya adalah: "kita harus berani menata ulang nurani kita yang sudah bobrok digantikan dengan nurani kemanusiaan yang sadar akan jatidirinya, karena manusia telah lupa akan jatidirinya," maka perlu terapi yang tepat guna; contoh datangnya bencana tergantung pada sikap manusia terhadap sesama, alam dan Tuhannya, sehingga manusia harus ingat akan asalnya dari mana, untuk apa dan mau ke mana (Sangkan Paraning Dumadi). Berkaitan dengan hal itu, rangkaian upacara ritual yang dilakukan oleh Sanggar Supranatural Sangga Buwana adalah untuk melestarikan kebudayaan Jawa.

Dalam surat kabar "Bernas Jogja” Jumat Pon, 8 September 2006 halaman 1 dan 6, dipaparkan bahwa penyelenggaraan ritual akbar dan doa bersama di Parangkusuma pada tanggal 7 September 2006, bertujuan untuk: (a) mengembalikan jatidiri bangsa; (b) memohon ampun atas dosa yang telah diperbuat; dan (c) memohon agar tidak ada lagi bencana yang berkelanjutan. Sebanyak 21 tumpeng, satu tumpeng besar buahbuahan dan ubarampe lainnya disiapkan dalam ritual itu. Gempar Andrajati, salah seorang panitia penyelenggara upacara, menjelaskan bahwa acara tersebut berawal dari adanya keprihatinan terhadap krisis budaya di negara ini. Hal-hal yang berkaitan dengan tradisi mulai ditinggalkan, kalau pun ada hanya sebentuk seremonial. Acara yang digelar di Parangkusuma itu merupakan titik tolak rekonsiliasi nasional melalui budaya. Dengan cara ritual akbar dan doa bersama akan lebih halus untuk dapat menyatukan nilai-nilai budaya yang terserak, sehingga menjadi satu kesatuan yang utuh. Selain itu Prasetyo, anggota panitia yang lain, menambahkan bahwa acara tersebut juga bermaksud untuk membangkitkan Bantul seperti sediakala, yakni sebagai Bantaling Tuladha atau fondasi keteladanan.

Upacara labuhan yang diselenggarakan pada hari Kamis 7 September 2006 diberi judul: "Ritual Akbar dan Doa Bersama 
Bangkitkan Bangsa dan Mencegah Terjadinya Bencana,” sedangkan pada hari Kamis 2 Februari 2007 berjudul "Ritual Akbar dan Doa Bersama dengan Tujuan Reformasi Nurani agar Manusia Kembali pada Jatidiri,” maksudnya untuk menghormati Kanjeng Ratu Kidul dan meneruskan tradisi nenek moyang. Dalam upacara ritual tersebut tidak dipergelarkan tari Bedaya Ketawang, karena tari itu milik raja dan hanya dipergelarkan setiap tahun sekali untuk memperingati jumenengan raja. Tari Bedaya Semang di Kraton Yogyakarta juga merupakan tari yang sakral seperti Bedaya Ketawang di Surakarta.

Bergayutan dengan hal itu, sejak tahun 2006 upacara labuhan Sanggar Supranatural Sangga Buwana menggunakan tari bedaya gaya Yogyakarta yang diciptakan oleh Jiyu Wijayanti dan dinamakan "Bedaya Sangga Buwana." Alasan penggunaan tari bedaya dalam upacara labuhan, karena untuk menambah khidmat jalannya ritual dan tari itu sangat lekat dengan mitos yang berkembang dalam kehidupan masyarakat Jawa, khususnya Yogyakarta; ritual dan mitos merupakan satu kesatuan dan tidak dapat dipisah-pisahkan, bahkan ritual dalam masyarakat tradisional untuk mendukung dan melestarikan mitos yang ada. Mengingat Parangkusuma sebagai tempat ziarah, maka kehadiran tari Bedaya Sangga Buwana dalam upacara itu juga merupakan daya tarik tersendiri bagi para wisatawan-ziarah. Selain itu juga karena tari bedaya sebagai tarian sakral jarang dipentaskan bagi khalayak ramai.

Tari Bedaya Sangga Buwana dalam upacara labuhan itu bermakna tari ritual yang mantra-mantranya memiliki kekuatan spiritual tingkat tinggi. Tidak ada upaya untuk menyaingi kekuasaan raja, tetapi hanya untuk melestarikan dan mengembangkan nilai-nilai budaya melalui tradisi nenek moyang kita. Selain layak dilestarikan, upacara dan ritual tradisional juga dapat menjadi wahana hubungan lintas budaya yang berperan positif untuk membangun saling pengertian dan persahabatan di antara bangsa-bangsa di dunia. Dari sudut pandang industri pariwisata, kegiatan budaya merupakan atraksi yang sangat berarti, sebagai promosi untuk menarik wisatawan asing yang ingin tahu kekayaan tradisi Jawa khususnya. Kita sebagai penerus akan terus meningkatkan jumlah inventarisasi dan dokumentasi warisan budaya. Perihal pemakaian warna hijau pada tata busana para penari bedaya tidak berarti menantang Penguasa Laut Selatan, Kanjeng Ratu Kidul, tetapi hanya bertujuan untuk membangkitkan satu Roh Penguasa Laut Selatan agar tetap membantu atau selalu melindungi tanah Jawa sesuai dengan perjanjian 
dahulu. Kanjeng Ratu Kidul berjanji akan selalu melindungi Kerajaan Mataram dari musibah apa pun dan Panembahan Senapati juga terikat dengan janji yang tidak boleh dilanggar, siapa pun yang jumeneng nata harus menjadi suami Kanjeng Ratu Kidul tanpa terkecuali.

Dengan demikian, juga menurut Wijayanti, keberadaan tari bedaya dalam upacara labuhan yang telah dipaparkan tidak berdiri sendiri sebagai seni pertunjukan, tetapi benar-benar terkait dengan atau menyesuaikan kebutuhan upacara ritual tersebut. Mengingat penyelenggara upacara ritual itu komunitas Sanggar Supranatural Sangga Buwana, maka tari bedaya sebagai sarana upacaranya juga dinamakan "Bedaya Sangga Buwana.” Tema tarinya adalah "kepasrahan,” karena bertolak dari makna upacara itu sendiri yang antara lain mengungkapkan rasa syukur atas keberhasilan karya-karya yang telah dilakukan dan memohon keselamatan, tidak terjadi bencana apa pun. Gagasan tentang tema itu diungkapkan ke dalam bentuk tari bedaya yang ditarikan oleh sembilan penari putri, melalui gerak-gerak tari putri gaya Yogyakarta dengan unsur-unsur pendukungnya antara lain: tata rias, tata busana, gending partner tari, properti dan ruang imajinasi estetis.

Dalam bentuk tersebut terkandung maksud atau isi kepasrahan diri, karena manusia sadar akan kesalahan yang telah dilakukan, introspeksi diri dan berusaha untuk mencapai keharmonisan. Selain yang dapat dilihat, isi tari bedaya juga dapat didengarkan melalui monolog dan syair atau cakepan tembang sebagai partner tarinya. Isi dan bentuk merupakan satu kesatuan dan tidak dapat dipisahkan. Bahkan isi, bentuk dan teknik dapat memproyeksikan makna yang penafsirannya satu sama lain berbeda, tergantung pada potensi penafsirnya dan dapat pula tidak sama dengan maksud pencipta tari itu sendiri. Berkaitan dengan hal itu, penata tari Bedaya Sangga Buwana, dengan kesadaran menciptakan isi kepasrahan diri ke dalam gerak-gerak dan gending-gending partner tarinya termasuk bagian vokal. Dalam pemilihan dan penciptaan gerakgerak tari putri bukan tanpa alasan melainkan ada maksud dan tujuannya terutama kontekstual dengan makna upacara ritual yang mendasarinya.

Tidak berbeda halnya dengan pemilihan tata rias paes manten dan warna hijau pada tata busana kesembilan penarinya, juga kontekstual dengan makna upacara ritual tersebut. Warna hijau menjadi pantangan bagi masyarakat yang percaya, tidak dipakai di sekitar pantai selatan, tetapi kenyataan juga banyak yang memakainya. Berkaitan dengan hal ini, apabila ada kesalahan atau pelanggaran yang terjadi dalam 
pertunjukan tari karena tidak disengaja adalah tanggung jawab pimpinan upacara (Sanggar Supranatural Sangga Buwana), Lia Hermin Putri. Upaya mempergelarkan tari bedaya bukan suatu pekerjaan yang mudah, karena selain membutuhkan dana yang tidak sedikit juga perlu persiapan dan latihan yang sangat rumit. Namun demikian, Sanggar Supranatural Sangga Buwana telah bertekad bulat untuk menjaga dan melestarikan, bahkan siap menjadi benteng terakhir guna mempertahankan kebudayaan adiluhung peninggalan nenek moyang. Tidak diharapkan nilai-nilai budaya adiluhung itu hilang karena manusia alpa dan selalu berorientasi pada masa kini. Sosio kultural yang dipengaruhi oleh paham asing semakin menjauhkan manusia dari dirinya sendiri dan lebih menakutkan bila jauh dari budaya sendiri. Oleh sebab itu, event Ritual Akbar dan Doa Bersama di Parangkusuma merupakan terapi untuk mewujudkan kembalinya kejayaan Bangsa Indonesia melalui budaya dan tradisi adiluhung. Diharapkan kegiatan itu dapat menjembatani "Rekonsiliasi Nasional melalui Budaya” dibarengi dengan menata nurani masingmasing. Hati nurani inilah yang kini telah terkikis di muka bumi ini. Keseimbangan antara akal dan hati tidak lagi dihiraukan, sehingga olah rasanya kurang (wawancara dengan Putri, pada 24-7-2008).

Dijelaskan lebih lanjut bahwa sebelum seluruh rangkaian upacara ritual berlangsung, juga dilakukan wisata-ziarah oleh para pelakunya, ke tempat-tempat keramat secara berurutan, yakni: makam Ki Ageng Giring, mBang Lampir, Kota Gede, Imagiri, Barat Ketiga, Sela Ning, Syekh Maulana Magribi, Syekh Bela-Belu, Batu Gilang dan Pantai Parangkusuma. Tujuannya antara lain mendoakan para leluhur agar mendapat tempat yang layak di sisi Tuhan dan diampuni dosa-dosa mereka, juga mohon keselamatan bagi seluruh umat dan terhindar dari bencana alam. Dengan demikian, dapat dikatakan bahwa upacara ritual labuhan dan wisata-ziarah merupakan satu kesatuan dan tidak dapat dipisah-pisahkan. Tidak berbeda halnya dengan seni pertunjukan ritual dan wisata-ziarah, juga merupakan satu kesatuan dan tidak dapat dipisahpisahkan, karena sebelum pertunjukan berlangsung para pelakunya juga melakukan wisata-ziarah. Namun demikian, keterkaitan seni petunjukan ritual (Bedaya Sangga Buwana) dan upacara ritual labuhan Sanggar Supranatural Sangga Buwana, sejak tahun 2006 hingga sekarang memang merupakan satu kesatuan, tari itu sebagai sarana upacara, tetapi masih dapat dipisahkan. Terbukti upacara ritual sejak sanggar tersebut berdiri (2003) hingga tahun 2005, tidak melibatkan seni pertunjukan 
tari bedaya juga tidak ada masalah. Dengan kata lain, tari Bedaya Sangga Buwana yang bertemakan "kepasrahan," yang diciptakan untuk memenuhi kebutuhan upacara ritual itu, dapat berdiri sendiri terpisah dari rangkaian upacara. Sudah barang tentu sebagai seni pertunjukan ritual yang berdiri sendiri, tari bedaya tersebut diberi judul yang berbeda, bukan Bedaya Sangga Buwana, karena judul merupakan identitas. Nama tari bedaya tidak harus diambilkan dari nama gending pokok partner tarinya, tetapi dapat dirumuskan dari segi yang lain dan hal ini merupakan kreativitas tersendiri bagi penata tari tersebut. Apalagi mengingat semakin maraknya wisatawan-ziarah, perlu dilakukan inovasi dengan berbagai aspek estetis koreografis untuk memunculkan kemasan seni pertunjukan wisata-ritual, sehingga tidak hanya sekadar mengubah judul tarinya.

\section{PERTUNJKAN RITUAL DALAM PERSPEKTIF ETNOART}

Parangkusuma merupakan nama salah satu lokasi yang dipandang keramat di Kawasan Pantai Parangtritis. Dikatakan keramat antara lain karena lokasi itu pernah dipakai untuk pertemuan Sutawijaya (Panembahan Senapati) dengan Kanjeng Ratu Kidul, yang ditandai dengan dua "Batu Gilang” Dalam budaya Jawa, lokasi tersebut dianggap sebagai gerbang utama menuju Kraton Gaib Laut Selatan, tempat tokoh mitos Kanjeng Ratu Kidul memerintah, maka upacara-upacara labuhan oleh masyarakat, baik kraton maupun masyarakat umumnya, diselenggarakan di Pantai Parangkusuma.

Dalam setiap masa krisis diperlukan hadirnya sesuatu yang transenden dan semua itu dilakukan melalui upacara. Upacara dengan sarana kesenian tetap bertolak dari makna upacara itu sendiri. Ketika terjadi krisis bersama, manusia menghadirkan kekuatan kosmos untuk mengatasi krisis itu, misalnya menyelenggarakan upacara labuhan, bersih desa dan sebagainya. Konsep kesatuan kosmos hanya dapat diperoleh melalui sistem kepercayaan, maka pengetahuan tentang kosmologi kepercayaan mereka menjadi sangat utama. Manusia Jawa menghadirkan Yang Ilahi atau Yang Suci dalam kehidupan melalui praktik-praktik keagamaan atau mitologi. Kehadiran Yang Suci itu diharapkan untuk menjaga keseimbangan dunia dan agar tidak terjadi berbagai gangguan atau bencana alam menimpa kehidupan manusia. Pandangan-pandangan masyarakat Jawa terhadap dunianya ini benar- 
benar dihayati dan mitos digunakan sebagai pegangan dalam kehidupannya. Mitologi Kanjeng Ratu Kidul sangat berpengaruh terhadap kehidupan mereka, bahkan hampir seluruh orang Jawa mengenalnya selaku penguasa Laut Selatan. Hal ini sebagai bukti bahwa mitologi Kanjeng Ratu Kidul telah menjadi warisan budaya yang diwariskan secara turun-temurun.

Dalam aktivitas ini terjadi hubungan sakral antara Kanjeng Ratu Kidul dan komunitas atau masyarakat yang menyelenggarakan upacara melalui getaran jiwa, ekspresi perasaan atau emosi, dan suara batin. Peristiwa ini juga terjadi bagi para pelaku wisata-ziarah, karena ketika mereka berdoa, bersemadi, bermeditasi untuk memohon keselamatan, ketenteraman dan perlindungan, juga terjadi upacara ritual dan hubungan sakral dengan Kanjeng Ratu Kidul melalui getaran jiwa, ekspresi perasaan atau emosi dan suara batin. Dengan demikian antara upacara ritual dan wisata-ziarah ada hubungan timbal balik, yakni dalam upacara ritual terjadi wisata-ziarah, sebaliknya dalam wisata-ziarah terjadi pula upacara ritual.

Dalam era modernisasi ini, kebudayaan Jawa yang berkaitan dengan Parangkusuma, upacara ritual labuhan dan kepercayaan mitos Kanjeng Ratu Kidul, yang sering dianggap tidak rasional, ternyata masih dilestarikan dan dikembangkan oleh masyarakat atau komunitas pemiliknya. Bahkan berpengaruh dalam kehidupan sehari-hari khususnya bagi masyarakat di sekitarnya. Dalam usaha untuk memohon keselamatan, ketenteraman lahir batin, terhindar dari bencana alam dan sebagainya, Parangkusuma dijadikan sasaran untuk berwisata-ziarah dengan cara mengadakan upacara ritual selamatan, labuhan, bersemadi, bermeditasi atau berdoa yang menurut kepercayaan masyarakatnya merupakan persembahan kepada Kanjeng Ratu Kidul penguasa Laut Selatan, walaupun semuanya itu ditujukan kepada Tuhan.

Dengan adanya mitos pertemuan Kanjeng Ratu Kidul dengan Sutawijaya, maka tiada mustahil bila atas dasar kepercayaan mitos, masyarakat di lingkungan kraton dan pedesaan khususnya di sekitar Parangkusuma selalu menyelenggarakan upacara ritual labuhan. Salah satu upacara labuhan yang menggunakan seni pertunjukan tari adalah upacara labuhan yang diselenggarakan oleh komunitas Sanggar Supranatural Sangga Buwana pimpinan Lia Hermin Putri, yang berdiri pada tanggal 22 Juli 2003 di Parangtritis. Mengingat keberadaan tari itu dilatarbelakangi oleh kebutuhan upacara ritual oleh Sanggar Supranatural 
Sangga Buwana, maka tari bedaya ciptaan Jiyu Wijayanti itu disebut Bedaya Sangga Buwana.

Alasan penggunaan tari bedaya dalam upacara labuhan, karena untuk menambah khidmat jalannya ritual dan tari itu sangat lekat dengan mitos yang berkembang dalam kehidupan masyarakat Jawa khususnya Yogyakarta; ritual dan mitos merupakan satu kesatuan dan tidak dapat dipisah-pisahkan, bahkan ritual dalam masyarakat tradisional untuk mendukung dan melestarikan mitos yang ada. Mengingat Parangkusuma sebagai tempat ziarah, maka kehadiran tari Bedaya Sangga Buwana dalam upacara itu juga merupakan daya tarik tersendiri bagi wisatawanziarah. Selain itu juga karena tari bedaya sebagai tarian sakral jarang dipentaskan bagi khalayak ramai. Tari Bedaya Sangga Buwana dalam upacara labuhan itu bermakna tari ritual yang mantra-mantranya memiliki kekuatan spiritual tingkat tinggi. Tidak ada upaya untuk menyaingi kekuasaan raja, tetapi hanya untuk melestarikan dan mengembangkan nilai-nilai budaya melalui tradisi nenek moyang. Selain layak dilestarikan, upacara dan ritual tradisional juga dapat menjadi wahana hubungan lintas budaya yang berperan positif untuk membangun saling pengertian dan persahabatan di antara bangsa-bangsa di dunia. Dari sudut pandang industri pariwisata, kegiatan budaya merupakan atraksi yang sangat berarti, sebagai promosi untuk menarik wisatawan asing yang ingin tahu kekayaan tradisi Jawa khususnya.

\section{SIMPULAN}

Keberadaan tari Bedaya dalam upacara labuhan tidak berdiri sendiri sebagai seni pertunjukan, tetapi benar-benar terkait dengan kebutuhan upacara ritual. Tema tarinya adalah "kepasrahan,” karena bertolak dari makna upacara itu sendiri yang antara lain mengungkapkan rasa syukur atas keberhasilan karya-karya yang telah dilakukan dan memohon keselamatan, tidak terjadi bencana apa pun. Gagasan tentang tema itu diungkapkan ke dalam bentuk tari bedaya yang ditarikan oleh sembilan penari putri, melalui gerak-gerak tari putri gaya Yogyakarta dengan unsur-unsur pendukungnya antara lain: tata rias, tata busana, gending pengiring tari, properti dan ruang imajinasi estetis.

Dalam bentuk tersebut terkandung maksud atau isi kepasrahan diri, karena manusia sadar akan kesalahan yang telah dilakukan, introspeksi diri dan berusaha untuk mencapai keharmonisan. Selain yang 
dapat dilihat, isi tari bedaya juga dapat didengarkan melalui monolog dan syair atau cakepan tembang sebagai partner tarinya. Isi dan bentuk merupakan satu kesatuan dan tidak dapat dipisahkan. Bahkan isi, bentuk dan teknik dapat memproyeksikan makna yang penafsirannya satu sama lain berbeda, tergantung pada potensi penafsirnya dan dapat pula tidak sama dengan maksud pencipta tari itu sendiri dengan kesadarannya. Isi atau makna kepasrahan diri ke dalam gerak-gerak dan gending-gending partner tarinya termasuk juga bagian vokal. Dalam pemilihan dan penciptaan gerak-gerak tari putri bukan tanpa alasan melainkan ada maksud dan tujuannya terutama kontekstual dengan makna upacara ritual yang mendasarinya. Tidak berbeda halnya dengan pemilihan tata rias paes manten dan warna hijau pada tata busana kesembilan penarinya, juga kontekstual dengan makna upacara ritual.

Dijelaskan lebih lanjut bahwa sebelum seluruh rangkaian upacara ritual berlangsung, dilakukan wisata-ziarah oleh para pelakunya, ke tempat-tempat keramat secara berurutan, yakni: makam Ki Ageng Giring, Mbang Lampir, Kota Gede, Imagiri, Barat Ketiga, Sela Ning, Syekh Maulana Magribi, Syekh Bela-Belu, Batu Gilang dan Pantai Parangkusuma. Tujuannya antara lain mendoakan para leluhur agar mendapat tempat yang layak di sisi Allah dan diampuni dosa-dosa mereka, juga mohon keselamatan bagi seluruh umat dan terhindar dari bencana alam. Dengan demikian, dapat dikatakan bahwa upacara ritual labuhan dan wisata-ziarah merupakan satu kesatuan dan tidak dapat dipisah-pisahkan. Tidak berbeda halnya dengan seni pertunjukan ritual dan wisata-ziarah, juga merupakan satu kesatuan dan tidak dapat dipisahpisahkan, karena sebelum pertunjukan berlangsung para pelakunya juga melakukan wisata-ziarah. Namun demikian, keterkaitan seni petunjukan ritual (Bedaya Sangga Buwana) dan upacara ritual labuhan Sanggar Supranatural Sangga Buwana, sejak tahun 2006 hingga sekarang (2008) memang merupakan satu kesatuan, tari tersebut sebagai sarana upacara, walaupun masih dapat dipisahkan. Terbukti upacara ritual sejak sanggar tersebut berdiri (2003) hingga tahun 2005, tidak melibatkan seni pertunjukan tari bedaya juga tidak ada masalah. Dengan kata lain, tari bedaya yang bertemakan "kepasrahan,” yang diciptakan untuk memenuhi kebutuhan upacara ritual itu, dapat berdiri sendiri terpisah dari rangkaian upacara. Sudah barang tentu sebagai seni pertunjukan ritual yang berdiri sendiri, tari bedaya tersebut diberi judul yang berbeda, bukan Bedaya Sangga Buwana, karena judul merupakan identitas. Nama tari bedaya 
tidak harus diambilkan dari nama gending pokok partner tarinya, tetapi dapat dirumuskan dari segi yang lain dan hal ini merupakan kreativitas tersendiri bagi penata tarinya. Apalagi mengingat semakin maraknya wisatawan-ziarah, perlu dilakukan inovasi dengan berbagai aspek estetis koreografis untuk memunculkan kemasan seni pertunjukan wisata-ritual, sehingga tidak hanya sekadar mengubah judul tarinya.

\section{DAFTAR RUJUKAN}

Album Jumenengan Dalem Sri Sultan Hamengku Buwana X. 1989, Yogyakarta: Kedaulatan Rakyat.

Dibia, I Wayan, F.X. Widaryanto \& Endo Suanda. 2006, Tari Komunal, Jakarta: Lembaga Pendidikan Seni Nusantara.

Dillistone, F.W. 1986, The Power of Symbols atau Daya Kekuatan Simbol, terjemahan A. Widyamartaya (2002), Yogyakarta: Kanisius.

Djelantik, A.A.M. 1999, Estetika: Sebuah Pengantar, Bandung: Masyarakat Seni Pertunjukan Indonesia.

Eliade, Mircea. 1957, Myths, Dreams and Mysteries, United States of America: Libraire Gallimard.

Ellfeldt, Lois 1977, Pedoman Dasar Penata Tari, terjemahan Sal Murgiyanto (1977), Jakarta: Lembaga Pendidikan Kesenian Jakarta.

Fernandez, Cosmas. 2002, Ziarah Sang Pelayan Ziarah Manusia, Yogyakarta: Kanisius.

Graburn, Nelson N.H. (editor). 1976, Ethnic and Tourist Arts: Cultural Expressions from the Fourth World, London: University of California Press, LTD.

Jaeni. 2007, Komunikasi Seni Pertunjukan: Membaca Teater Rakyat Indonesia (Sandiwara Cirebon), Bandung: Etnoteater Publisher. Kleiden, Ignas. 1988, Sikap Ilmiah dan Kritik Kebudayaan, Jakarta: Lembaga Penelitian, Pendidikan \& Penerangan Ekonomi \& Sosial. Koentjaraningrat. 1987, Sejarah Teori Antropologi I, Jakarta: Universitas Indonesia (UI-Press).

Koentjaraningrat.1990, Sejarah Teori Antropologi II, Jakarta: Universitas Indonesia.

Kuntowijoyo. 1987, Budaya dan Masyarakat, Yogyakarta: Tiara Wacana M., Saini K. 2004, Krisis Kebudayaan, Bandung: Kelir. 
Seni Pertunjukan Ritual dalam... (Y. Murdiyati)

Soedarsono, R.M. 1999, Seni Pertunjukan Indonesia dan Pariwisata, Bandung: Masyarakat Seni Pertunjukan Indonesia.

Subgya, Rahmat. 1976, Kepercayaan-Kebatinan, Kerohanian, Kejiwaan dan Agama, Yogyakarta: Kanisius.

Sumardjo, Jakob. 2000, Filsafat Seni, Bandung: ITB.

Twikromo, Y. Argo. 2006, Mitologi Kanjeng Ratu Kidul, Yogyakarta: Nidia Pustaka.

Waridi dan Bambang Murtiyoso (ed). 2005, Seni Pettunjukan Indonesia: Menimbang Pendekatan Emik Nusantara, Surakarta: The Ford Foundation dan Program Pendidikan Pascasarjana Sekolah Tinggi Seni Indonesia Surakarta.

\section{Nara Sumber}

Lia Hermin Putri

Jiyu Wijayanti 